\title{
Offering Support and Sharing Experiences: Indonesia's Approach to Peacebuilding
}

\author{
Lina A. Alexandra
}

\section{INTRODUCTION}

Compared to peacekeeping, the term peacebuilding receives relatively less attention among Indonesian policymakers and society. Indonesia's active contribution to United Nations peacekeeping since 1957, not too long after its independence, has often been showcased as one of the country's greatest achievements in the maintenance of international peace and security.

However, this should not lead to the conclusion that Indonesia is not playing any role within the peacebuilding arena. This is partly because peacebuilding has been understood in a much broader sense than peacekeeping. In the Indonesian context, peacebuilding, rather than viewed as direct efforts to prevent another lapse into conflict in post-conflict societies, is understood as different kinds of activities that can contribute to conflict prevention and conflict management. Indonesia focuses its peacebuilding efforts on sharing its experiences and knowledge in democracy as a key to sustaining peace, playing a role as mediator/facilitator/

L.A. Alexandra $(\bowtie)$

Centre for Strategic and International Studies (CSIS), Jakarta, Indonesia

(C) The Author(s) 2017

C.T. Call, C. de Coning (eds.), Rising Powers and

Peacebuilding, Rethinking Peace and Conflict Studies, DOI 10.1007/978-3-319-60621-7_3 
observer, and conducting humanitarian actions that can help initiate the peace process.

While Indonesia has been involved in mediation activities for decades, this peacebuilding role developed more robustly during the ten years of President Yudhoyono's administration from 2004 to 2014. The transition from the authoritarian regime of the New Order era to a democratic government led to greater stability, marked by the ability of the government to initiate peace processes that led to the settlement of various internal conflicts, and also the implementation of the first direct presidential election in the country. Despite some problems, the transition went smoothly and the country avoided violent revolution, which was predicted by many observers. These experiences of democratic transition, which included installing the civilian government, returning the military to the barracks, and settling internal conflicts, have been considered valuable lessons which can be shared with other countries that are currently struggling with similar challenges.

This willingness to share experiences and lessons learned has been seen as part of Indonesia's soft power to be projected in order to achieve its vision of becoming a middle power. As Indonesia gradually transforms itself from an aid recipient into an emerging donor or development partner, peacebuilding has become one of the key areas in which the government assists other countries that are struggling to rebuild their core political and economic infrastructures in order to achieve sustainable peace.

This policy brief explores how peacebuilding is understood in Indonesia, including any novel insights that can be drawn from its understanding of the concept; the principles/philosophies that underlie peacebuilding, the motivating factors, and the existing debate about peacebuilding; and finally descriptions of peacebuilding activities and how the results of those activities implemented abroad have been measured. Rather than exploring Indonesia's unilateral role per se, the elaborations also include Indonesia's role in the context of ASEAN (Association of Southeast Asian Nations), since the country has often worked through the framework of the regional organization, and Indonesia is often perceived by others as the "natural leader' of ASEAN.

The policy brief begins with a brief explanation of the historical evolution of Indonesia's peacebuilding efforts. For the purpose of this study, it traces back only to the so-called peacebuilding activities in the New Order era up to the post-reformation era under President Yudhoyono's (2004-2014) administration. This historical evolution is important 
to show a sense of continuity in the values and principles applied to Indonesia's foreign policy, including in peacebuilding activities abroad. However, as is often the case, pragmatism sometimes takes precedence over a values-based approach to foreign policy.

The Indonesian approach to peacebuilding is distinct in at least two ways. First, it emphasizes persuasion to encourage host countries to think of ways to create peace in their respective countries, particularly through intensive dialogues with local stakeholders. Rather than taking place solely at the formal level, such dialogues have often been conducted on an informal basis to engage non-state actors, such as think-tanks and nongovernmental organizations. Second, Indonesia emphasizes the concept of 'sharing' experiences. Rather than acting as an expert conveying its success stories, Indonesia tends to apply a two-way approach in which it not only shares its own experiences, but also learns from the host country and works to understand the local context while seeking the local 'modalities' to be utilized in order to start the peacebuilding process. Indonesia does not advocate a 'one-size-fits-all' peacebuilding policy since each country has its own unique challenges and context. Respect for these conditions is considered key to successful peacebuilding.

\section{Historical Evolution of Indonesia's Role in Peacebuilding: New Order to Post-reformation Era}

Rather than understanding peacebuilding strictly as a set of activities conducted in the aftermath of conflict, Indonesia interprets the concept more broadly. In the New Order era (1966-1998) under President Soeharto, such activities were mainly focused on conflict management, which entailed mediation or facilitation roles. In the post-reformation era under President Yudhoyono, Indonesia has also shared its experiences and lessons learned in democratization and dealing with internal conflicts.

Any discussion of Indonesia's peacebuilding roles must be placed within the context of the country's overall foreign policy.

During the first decade of his term starting in 1966, President Soeharto abandoned Soekarno's flamboyant style and high-profile foreign policy, instead focusing on economic development. Foreign policy initiatives were directed to invite foreign investment, mainly from Western countries and international financial institutions to finance its development plan. 
Rather than playing an assertive role like in the Old Order era under President Soekarno, from the late-1960s through the mid-1980s, Indonesia took a lower profile, focusing on economic growth and development, which was seen as the path toward a more assertive role internationally in the long term. In his remarks in August 1969, Soeharto elucidated this logic: 'Why is the voice of Indonesia no longer heard abroad? The matter is that we shall only be able to play an effective role if we ourselves are possessed of a great national vitality' (Leifer 1983). It was not until the 1980s, after the 'Asian economic miracle' and a period of sustained growth, that Indonesia started to play a more active role, initially within Southeast Asia.

Two cases are often quoted as examples of successful peace efforts by Indonesia. The first is the end of the long Cambodian armed conflict. Working within the framework of ASEAN, Indonesia hosted the Jakarta Informal Meeting I in Bogor in July 1988 and the Jakarta Informal Meeting II in Jakarta in October 1989, which culminated in the historical Paris Peace Agreement in late October 1991. As depicted by former Foreign Minister Ali Alatas, Indonesia, interlocutor for ASEAN, these two meetings sought to facilitate dialogue, first among the four Cambodian factions and second among those factions and Indonesia, Vietnam, and other concerned countries (Alatas 2001, 270). ASEAN, including Indonesia, worked hard to keep international attention on the Cambodian conflict and to end Vietnam's occupation in Cambodia. Ultimately changing international circumstances at the end of the Cold War led Vietnam to withdraw its forces in April 1989 (Narine 1998, 207).

The second case is Indonesia's involvement in facilitating the peace process between the Government of Philippines and the Moro National Liberation Front (MNLF) for two decades. According to Wiryono Sastrohandoyo, a seasoned Indonesian diplomat who once acted as a mediator of conflicts in Mindanao, soon after the rebellion broke out in late 1972, President Soeharto suggested that President Marcos settle the conflict through the mechanism of ASEAN. However, seeking to secure oil from the Middle East, Marcos decided to bring the case to the Organization of the Islamic Conference (OIC) instead. The process under OIC resulted in the signing of Tripoli Agreement in December 1976, but the agreement could not be implemented. Further discussions considering the establishment of an autonomous Muslim region in the southern Philippines were halted as hostilities among the parties resumed. The peace agreement was hampered even more as the Marcos administration insisted on implementing it without the participation of the MNLF. 
Only at its Ministerial Meeting in 1991 did the OIC) decide to expand the committee to include member countries from Asia. This development was also supported by the new Philippine government of President Corazon Aquino. At that time, the OIC) Secretariat asked Indonesia to help facilitate the peace process. In 1993, Indonesia was elected Chair of the OIC) Ministerial Committee of Six, of which fellow Asian country Bangladesh was also a member. In April 1993, Indonesia hosted a second round of informal exploratory talks in Cipanas, West Java, which resulted in a 'Statement of Understanding' that called for formal peace talks that would discuss the modalities to fully implement the Tripoli Agreement. The first round of formal peace talks was held in October-November 1993, which resulted in the signing of a Memorandum of Agreement and the 1993 Interim Ceasefire Agreement. After a series of meetings at the technical level, informal consultations and formal peace talks, the peace agreement was then signed between the Government of the Philippines and the MNLF in Manila in September 1996. Ambassador Sastrohandoyo, discussing Indonesia's crucial role in forging the agreement, said:

This is a case of preventive diplomacy, peacemaking, and peace-building in which the United Nations (UN) was not involved at all. Instead it was an international organization with a religious orientation, the OIC), which was mediating. Its efforts could make no headway, however, until two countries from the Asian region, one of them a next-door neighbour of the conflicted country, became involved. (Sastrohandoyo 2008, 19)

In the post-reformation era, the Yudhoyono government was again able to assume a more assertive role in the region after half a decade of internal domestic consolidation. Indonesia experienced serious political, security, and economic crises during the period of 1999-2003, in the aftermath of Soeharto's New Order regime. The impact of these crises was so severe that the economic growth declined and its political and military influenced waned in the immediate post-Soeharto years. Some analysts saw Indonesia as a 'wounded phoenix', unable to rise and pursue a robust foreign policy due to internal crises and lacking the strong leadership shown by Soeharto during New Order era (Weatherbee 2005).

It is interesting to observe how the post-reformation government under Yudhoyono tried to cope with its lack of 'hard' or material capabilities. The administration started to invest in projecting Indonesia's soft power, which 
mainly derives from the country's political transition experience from semiauthoritarianism to a democratic civilian-led government. By expanding this soft power, Indonesia has sought to nurture what the President called 'intellectual leadership', particularly in ASEAN. According to Yudhoyono, the country sought to be a 'peacemaker, confidence-builder, problemsolver, and bridge-builder' (Yudhoyono 2005, 387). Fully aware of its identity as a country with the largest Muslim population in the world, Indonesia portrayed itself as a genuine example where 'democracy, Islam and modernity can go hand-in-hand'.

However, in the early years, Yudhoyono's first term, the country was challenged by the tsunami disaster that hit Aceh in late December 2004, causing hundreds of thousands of deaths and destroying almost all the infrastructure in the province. The government gradually returned to its foreign policy activism again after two years, which is marked by the attendance of President Yudhoyono in the Non-Aligned Movement Summit in Havana in September 2006. At the summit, he declared Indonesia's aspiration to bridge the developed and developing worlds. One year later, Indonesia was able to secure several positions in the international arena, including a stint as a non-permanent member of the UN Security Council (2007-2009), and membership in the UN's Economic and Social Council (2007-2009) and Human Rights Council (2007). The year 2006 also marked a significant increase in Indonesia's peacekeeping contribution, when it contributed a total of 1058 personnel to five UN missions, including 850 troops for UNIFIL. By 2010, Indonesia was listed as one of top 20 largest troop contributing countries to UN peacekeeping, and was ranked sixteenth in 2014 .

In this context and in the area of peacebuilding, Indonesia expanded its role as a 'champion' of democracy in the region, as well as facilitator and peace observer. At the regional level, during the process to create the ASEAN Charter, Indonesia's late Foreign Minister Ali Alatas insisted that the principles of rule of law, good governance, democracy promotion, and protection of human rights to be included as the new principles of ASEAN. ${ }^{1}$ Later on, Indonesia took a leading role in the formulation process of the ASEAN Political Security Community Blueprint, which mandated the establishment of the ASEAN Human Rights Body-later named the ASEAN Intergovernmental Commission on Human Rights and the ASEAN Institute for Peace and Reconciliation-a new institution established in 2011 , which was specifically tasked to conduct research in peace and conflict resolution. 
At the bilateral level, Indonesia also offered to facilitate peace processes in other countries in the region. In 2008, the government explored potential involvement in facilitating the peace process in Southern Thailand, but the Thai government eventually rejected this. Then, starting in July 2012, Indonesia also participated in the International Monitoring Team (IMT) to monitor the implementation of the peace agreement between the Government of the Philippines and the Moro Islamic Liberation Front (MILF). Indonesia earned the trust of the Philippine government to participate in IMT until 2015. At the global level, in its effort to project democratic values as the foundation to create peace, Indonesia initiated the Bali Democracy Forum (BDF) in 2008. The forum, which invites Asia-Pacific leaders, aims to promote and foster regional and international cooperation in the field of peace and democracy through dialogue, allowing leaders to share their experiences and best practices. The Institute of Peace and Democracy (IPD), which was specifically created to organize the BDF, has been successful in convening an annual meeting. The eighth meeting of the BDF took place in 2015.

Before entering into more detailed elaborations in the next few sections, one can see through the historical evolution of Indonesia's peacebuilding activities some continuities and changes. Many of the values and principles that shape Indonesia's peacebuilding have remained the same. However, some changes have also been observed, particularly in the way adherence to the non-interference principle has been interpreted and applied in conducting peacebuilding activities.

From the analysis on Indonesia's worldview and foreign policy by Paige Johnson Tan, two major aspects show continuity. The first is the way Indonesia perceives its role in the region as well as in the world. Second, it is the country's underlying attitudes toward major powers and the world system as a whole. These two aspects reflect the doctrine, present since Suharto, that Indonesia's foreign policy be 'active and independent' (Tan 2007, 157).

The first aspect indicates the 'active' element in Indonesia's foreign policy. As a large country in the region, Indonesia believes it should play a significant role in establishing a 'world order' based on 'perpetual peace', as enshrined since 1945 in the preamble to the constitution. In the New Order era, after the country's economy grew significantly in late 1980s, the Soeharto government stated its intention to re-establish its active and assertive role in the world (Tan 2007, 159-160). Indonesia re-asserted this aspiration after domestic political and economic conditions improved 
in the post-reformation era, as lingering internal conflicts were settled. As mentioned by President Yudhoyono in the mid-2005, '...After all, we have today an Indonesia that is capable and eager to actively engage the international community in the common task of building a better world' (Yudhoyono 2005, 397).

The second aspect is Indonesia's 'independent' policy. After the bitter experiences of colonialism, Indonesia shared with other post-colonial countries the sentiment that the global system is still operated by and for the interests of the powerful countries. Therefore, in the Indonesian leaders' view, it is very important to be neutral as a nation-state, navigating between superpowers during the Cold War, and even lead the region along a neutral path. What typifies Indonesian thinking, however, is the idea that neutrality should lead each country to 'national resilience', which will then create 'regional resilience'. It means that each country and the region should come up with their own solutions to their own problems, limiting the interference of external powers in order to maintain stability. The first Foreign Minister of the Soeharto administration, Adam Malik, elaborated on this concept in 1971:

...However dominant the influence of these big powers may be, I think there is and there should be scope for an indigenous Southeast Asian component in the new emerging power balance of the region. In fact, I am convinced that unless the big powers acknowledge and the Southeast Asian nations themselves assume a greater and more direct responsibility in the maintenance of security in the area, no lasting stability can ever be achieved.

(Wulan and Bandoro 2007, 28)

The idea was reaffirmed during the post-reformation administration. When talking about the ASEAN Community, President Yudhoyono stated that 'we in ASEAN are taking full responsibility for our own security'(Yudhoyono 2005, 395). Indonesia's peacebuilding activities therefore value respect for the host country's sovereignty and focus on gaining confidence and trust from local stakeholders, who have the resilience to build sustainable peace.

While peacebuilding during the New Order era focused on playing a facilitator role, the Yudhoyono administration took a different route by sharing values that can contribute to creating sustainable peace, namely respect for democracy and human rights. The post-reformation government has stepped up its peacebuilding in the region, such as in Myanmar, 
where Indonesia assisted in implementing security sector reform to create military professionalism and separate the military from politics.

Several factors explain these different approaches. First, during the New Order era, Indonesia was governed by a military authoritarian regime, so even discussion about democracy and separation of the military from politics was unthinkable. Second, playing a facilitation role requires 'hard power', that is, economic and military strength in order to be able to influence conflicting parties to stop fighting and come to the negotiation table. Post-Soeharto governments are still struggling to rebuild that economic and military strength. As an alternative, Indonesia has developed and projected its soft power-values and wisdom gained from experiences during the political transition period.

\section{CONCEPTS And Terms}

In Indonesia, especially among policymakers, the term 'peacebuilding' has been translated into Bahasa Indonesian as 'bina perdamaian' (which literally means peacebuilding). However, most of the existing literature on peacebuilding in Indonesia has elaborated on peacebuilding activities inside the country, since Indonesia has been-and is still in some areasdealing with separatist and communal conflicts. No study has yet been conducted analyzing Indonesia's involvement in peacebuilding in other countries. This is not surprising, since interest in the topic is relatively novel. Therefore, the understanding of this type of 'external' peacebuilding is rather limited.

Peacebuilding in the Indonesian context, rather than viewed rigidly as a set of activities conducted after peace has been secured through peacekeeping missions, is applied more broadly as a variety of activities related to peace. Indonesia's external peacebuilding efforts can be identified in at least three areas: (1) promotion of democracy and human rights; (2) mediation/facilitation role; (3) humanitarian action, including disaster relief.

At the policy level, these external peacebuilding activities have been included in the democracy and conflict resolution program, one of the seven program priorities mentioned in the Draft Design for Indonesia's South-South Triangular Cooperation (SSTC) . ${ }^{2}$ The SSTC viewed peacebuilding as one of Indonesia's comparative advantages, together with good governance. ${ }^{3}$ From here, it is clear that peacebuilding is viewed as a capacity to be shared with other countries, and therefore has been put 
within the framework of Indonesia's development assistance, together with other capacities in economic and socio-cultural fields.

\section{Promotion of Democracy and Human Rights}

As mentioned earlier, Indonesia's experiences with peaceful democratic transition, despite some sectarian and communal conflicts as well as ethnic-based riots, are considered valuable modalities that can be shared with others that are facing similar challenges. There were fears that Indonesia, during this period of political turbulence, would be 'balkanized' into smaller regions along ethnic-religious lines. The ability to survive and maintain its unity and become a relatively 'healthy' state, in terms of its political and economic achievements, is something to value and learn about.

Indonesia's successful democratic transition is even more unique, given its status as the largest Muslim state. The fact that Indonesia has not become an Islamic state after the political reformation process, maintaining its status as a secular country, has been portrayed as evidence that Islam can go hand-in-hand with democracy. As mentioned by President Yudhoyono in 2005,

...We are home to the world's largest Muslim population. We are the world's third largest democracy. We are also a country where democracy, Islam, and modernity go hand-in-hand.... (Yudhoyono 2005, 390)

It is interesting to note that sharing its experience with democracy has been underlined as one of the seven program priorities in Indonesia's SSTC. ${ }^{4}$ The intention to build Indonesia's democracy promotion capacity grew following the Arab Spring, which started in Tunisia and later Egypt. Using the one- and second-track approaches, the Indonesian government, through the IPD, organized a workshop, in Jakarta in April 2012, that brought together delegates from Egypt, Tunisia, and Indonesia to discuss several issues, such as Islam, the state, and politics; political and constitutional reforms; election laws and management; the role of political parties and civil society; the army's role in democratic society; and the participation of women in the political process (Eliraz 2014).

Indonesia's ability to share its experience with democratic transition to assist other burgeoning Muslim majority democracies has been highlighted by other international observers. ${ }^{5}$ Australian diplomat Greg 
Moriarty, for example, argued that the Indonesian democratic transition served as a good example for the 'Arab Spring' countries that Islam and democracy can be compatible (Alford 2011).

Recently, Indonesia has also shown interest in promoting democracy to its fellow ASEAN member Myanmar. When it was under authoritarian rule, the country received harsh criticism from the international community due to serious human rights violations, including political repression by the military junta, making it ASEAN's 'Achilles heel'. Indonesia, since Myanmar's political opening, has looked to create pathways to promote democracy into the country. It started with the first formal visit of President Yudhoyono to Myanmar in 2006. It continued with the Second Forum of the Joint Commission for Bilateral Cooperation (JCBC) between Indonesia and Myanmar in 2011, which took place in Yangon, in which Foreign Minister Marty Natalegawa met with his Myanmarese counterpart, U Wunna Maung Lwin, and with Aung San Suu Kyi-the symbol of Myanmar's democratic struggle. On this occasion, the Indonesian Foreign Minister expressed the country's intention to work with Myanmar's government to support capacity building in the fields of good governance, democracy, and human rights (Maulida and Adamrah 2011).

\section{Mediation/Facilitation Role}

Indonesia's role as a mediator, facilitator, and observer is nothing new. As mentioned earlier, during the Cold War era, Indonesia was praised for its active role in the Cambodian peace process, organizing the Jakarta Informal Meeting I and Jakarta Informal Meeting II.

More recently, in the early 1990s, Indonesia was actively involved in brokering peace in the Southern Philippines. Indonesia has been particularly engaged in the peace process between the Government of the Philippines (GPH) and the MNLF) at the request of the Organization of Islamic Conference (OIC) forum, while Malaysia is more involved as a third-party facilitator between the GPH and the Moro Islamic Liberation Front (MILF). As mentioned earlier, Indonesia's facilitating role culminated in the First Round of Formal Peace Talks held in Jakarta in October-November 1993, which resulted in the signing of a Memorandum of Agreement and the 1993 Interim Ceasefire Agreement. Indonesian officers then also joined as members of the OIC) Observer Team that coordinated the implementation of the ceasefire agreement. Jakarta was chosen as the host of several follow-up meetings to establish 
a transitional structure and mechanism for the provincial government in the autonomous region, besides New York and Jeddah. Then, a peace agreement was reached between the GPH and the MNLF in September 1996 (Sastrohandoyo 2008, 15-30). While it is understood that peace is a process, Indonesia has continued its role as part of the IMT since 2012. Until 2014, at least four teams were sent to monitor peace in this area.

Indonesian non-governmental organizations (NGOs) have also played crucial facilitation roles. Muhammadiyah, an international nongovernmental organization (INGO) based in Indonesia, has participated in the International Contact Group, a hybrid mediation support initiative asked to provide support to the parties. ${ }^{6}$

Indonesia also attempted to act as a mediator in Southern Thailand between the Thai government and the Muslim groups residing in the southern part of the country. The Indonesian government, led by Vice President Jusuf Kalla (who now also serves as the Indonesian Vice President for the second time), managed to host a peace talk in Bogor in 2008 attended by Thai officials and representatives of insurgent groups. The effort did not produce an agreement and was later rejected by the Thai government since it insisted that the talks should be kept strictly domestic (The Jakarta Post 2010).

\section{Humanitarian Action}

While humanitarian action, including disaster relief, is normally separated from peacebuilding efforts, in the context of Indonesia, humanitarian assistance has been utilized to pave the way to conduct peacebuilding. This distinct feature has been created as a strategy to ensure that state sovereignty is respected, since humanitarian action is often considered less threatening than peacebuilding activities that can be perceived as challenging a government's capacity to deal with post-conflict situations. Furthermore, humanitarian assistance can be crucial to gaining trust from the host countries, since such efforts are often viewed as a gesture of good will. Humanitarian assistance can also be utilized to share experiences with disaster and crisis management.

Cyclone Nargis provides a good example of the usefulness of humanitarian assistance. In this context, Indonesia played a leading role in approaching the military junta in Myanmar and challenging it to open access to outside humanitarian aid to help the victims. Indonesia drew upon the experience of handling the impact of the tsunami disaster that hit Aceh in 
December 2004, in which the peace negotiations between the Indonesian government and the Aceh separatist movement resumed immediately after the tragedy took place. The Indonesian government saw an opportunity for the regime in Myanmar to open up to the outside world, which became another path to spread democratic and human rights values in the country through long-term and sustained engagement with international community. As elucidated by Foreign Minister Hassan Wirajuda in the wake of Cyclone Nargis disaster,

Based on our experience with tsunami, we want to make sure there's more after the relief phase. Reconstruction, rehabilitation and even prevention. We want to nurture that sense of wanting to open up on Myanmar's side to have a long-term engagement with the international community. (Hotland 2008)

Indonesia has also been actively involved in finding ways to help Myanmar's Rohingya minorities. Starting with the flow of Rohingya people stranded in Indonesia's territories, mostly in the northern tip of Sumatera island in 2012, the Indonesian government has been domestically pressured to help the group, which faces repression and discrimination in Myanmar. The local people, such as the Acehnese, have helped the Rohingya to get food, medication, and shelter after traveling through the Indian Ocean for months.

In September 2012, the Indonesian Red Cross (PMI) through its Chairman Jusuf Kalla, who was actively involved in the Aceh peace process while he served as Vice President, visited Myanmar and shared some best practices and suggestions based on the Indonesian experience in dealing with peace in Aceh, in a forum to discuss peaceful solutions to the civil conflict in Myanmar (Taufiqurrahman 2012b). He also signed an agreement with the Myanmar Red Cross to provide financial and technical assistance for short- and long-term programs that address the refugee crisis in the Rakhine state. Kalla stated that PMI would like to stay in the Rakhine state for the post-conflict reconstruction program (Taufiqurrahman 2012a). While PMI has received permission to conduct its activities in the country, unfortunately other humanitarian agencies, such as Médecins Sans Frontières-Holland (MSF-H), have been denied access since February 2014 to continue humanitarian activities in the country (Fan and Krebs 2014, 9-10). Despite these obstacles, the fact that PMI still has access should be seen as an opportunity for Indonesia to play a significant role in the country, especially to help resolve ethnic tensions. 
Looking at Indonesia's capacities, based on its experiences dealing with its own communal conflicts, since the late 2012 President Thein Sein has asked Indonesia to assist the Myanmar government in resolving the ongoing ethnic tensions that are taking place in the Rakhine state, where most Rohingya people have been displaced (Santosa 2012).

Recently, in late December 2016, the Indonesian government has once again taken the initiative to send humanitarian aid to the Rakhine state to ease the suffering of the people, especially the Rohingyas. The tension has risen in the area as the government responded through the military measure to search for the perpetrators after the attack against the police in the Mungdaw and Rathedaung townships in early October 2016. This action has been followed by the Indonesian government proposal to the OIC during the Extraordinary Ministerial Conference in Kuala Lumpur on January 19, 2017, which basically calls for it to conduct four things: (1) to offer humanitarian aid and security advice for avoiding further clashes; (2) to work closely with the Myanmar government; (3) to cooperate with regional organizations, such as ASEAN; and (4) for the OIC member countries to assist the country through economic development, with the possibility to get assistance from the Islamic Development Bank (Antara News 2017).

\section{Origins and Underlying Principles/Philosophy}

Based on the elaborations above, we can see that peacebuilding in the Indonesian context has been viewed rather differently from traditional actors. Peacebuilding, while it certainly entails activities to rebuild core government functions to prevent lapses into conflict, also includes supporting activities to build trust in order to allow more 'direct' peacebuilding efforts to take place. This is crucial since peacebuilding has been seen as external intervention by outside actors into a country's domestic affairs, which is sometimes considered a challenge to the host government's sovereignty.

Such distinct approaches also entail a set of unique principles. There are at least two principles to highlight.

The first principle is the importance of carefully considering the 'comfort' level of the host country in accepting the offer to help with a peacebuilding process, while at the same time seeking an entry point. This is critical to gaining the trust of the partner country and eventually determines the level of success achieved in this peacebuilding effort. The host 
government should reach the stage where it feels the need for and is comfortable enough to open up itself to receiving other countries' assistance in the peacebuilding process.

How to achieve that comfort level? First, it is done through persuasive action. For example, representatives from the Indonesian government approached Middle East countries such as Egypt and Tunisia in the midst of the Arab Spring uprisings to share Indonesia's democratic transition experiences. ${ }^{7}$

Second, Indonesia provides humanitarian assistance, such as the response to the devastative Cyclone Nargis caused in Myanmar. When the Myanmarese government was condemned for its refusal to give access to international humanitarian agencies to enter the country during Cyclone Nargis and even 'threatened' to receive a UN Security Council response under the 'Responsibility to Protect' (RtoP) principle, as proposed by the French government, Indonesia immediately rejected such a proposal. Indonesian Foreign Minister Marty Natalegawa argued that by invoking the RtoP principle, 'it would jeopardize and undermine aid work, not only for Myanmar, but also future humanitarian situations', since RtoP is only applied in situations related to the four serious crimes, that is genocide, ethnic cleansing, war crimes, and crimes against humanity (Hotland 2008). Indonesia has played an influential role to consolidate support from all ASEAN member countries for Myanmar's chairmanship bid in ASEAN for 2014. Indonesia viewed that ASEAN membership would motivate the Myanmarese government to further democratize and adopt more stringent human rights values (Adamrah 2011).

Consent from the host country is a must. While Indonesia often took the initiative in engaging with other countries, it always emphasized consultation with and consent from the host country. For example, when Indonesia offered assistance in monitoring the mid-term elections in Myanmar in 2012, it patiently waited for the signal from the Myanmarese government as to whether it needed an election monitoring team (Kompas, January 2012). Also, in the case of Southern Thailand, the Indonesian Foreign Minister stated that any request for assistance from the Thai government would be welcomed, but Indonesia would not interfere preemptively (The Jakarta Post 2010). Consent fosters a sincere engagement with the host government in the peacebuilding process. This reflects Indonesia's desire for the host government to feel confident that the offer of peacebuilding assistance will not challenge its sovereign control over its internal affairs. With this so-called constructive engagement, it is expected that Indonesia, 
in its efforts to conduct peacebuilding in other countries, will not burn bridges, but rather maintain its relations and be able to exercise influence and persuasion with other governments.

The second principle is 'sharing'. This concept of 'sharing' has been mentioned in almost every effort to help other countries in this peacebuilding context. Based on several interviews, this concept of 'sharing' has been defined in at least two ways. First, it is to emphasize that Indonesia has no intention to dictate or impose certain lessons or values to the host countries. According to the Executive Director of the Institute for Peace and Democracy, I Ketut Erawan, this approach has been taken because Indonesia believes that each country has local modalities/capacities to start its peacebuilding process. Furthermore, there are cases, such as in Myanmar, where the local stakeholders, including the government, asked Indonesia to share its experience in managing its ethnic relations. Related to Indonesia's initiative to support Myanmar in its democratic transition, as highlighted by the former Indonesian Foreign Minister Marty Natalegawa, Indonesia has been willing to be a 'study case' for any country to learn. Moreover, Minister Natalegawa stated that, 'With the approach that we are doing, they do not feel that they are being dictated because what we try is to share our experiences and lessons that we gained before...' (Kompas, February 2012). Second, the things that are shared are based on Indonesia's own experiences with democratic consolidation, among other challenges. Indonesia has also been open to share its mistakes and setbacks with the partner countries. By doing so, Indonesia has been able to secure trust and has more credibility, since it is not dictating the path forward for host countries. Thus, Indonesia also believes that there is no 'one-size-fits-all' recipe to build peace, since each country has its own distinct characteristics and challenges. Indonesia shares not only success stories, but also its past mistakes and failures. Therefore, each host country can choose what should be adapted to its own context.

Such principles are meant to accommodate respect for state sovereignty and non-interference in others' domestic affairs. Again, it is believed that the success of peacebuilding efforts depends on the ability of the actors to work at a pace that is in line with the standards of the host country, a pace that does not threaten the control of the host government over its own domestic sphere. This may be a long process, and is often criticized as ineffective by traditional peacebuilding actors, mainly Western countries, but building trust is considered essential for the success of peacebuilding programs. 
This leads to the question of whether the application of such principles actually positions external peacebuilding actors as weak vis-à-vis the host government. One senior Indonesian diplomat said that we should not forget the element of 'firmness' in any persuasive approach undertaken. This has been shown in the case when the former Foreign Minister Hassan Wirajuda approached the military junta in Myanmar to allow humanitarian aid. Wirajuda was able to put pressure on the junta by asking the Foreign Minister of Myanmar what ASEAN membership meant for Myanmar and what Myanmar's membership meant to ASEAN in terms of ASEAN's internal coherence and international profile (Widyaningsih and Roberts $2014,108)$. By explaining the consequences of not allowing ASEAN to play a role in responding to the disaster, the 'persuasive' effort resulted in the opening up of the country for the flow of humanitarian assistance.

\section{Motivations}

It is a daunting task to explore the drivers behind Indonesia's peacebuilding activities abroad. In interviews conducted with various government officials, most of them immediately referred to one of the country's national objectives stated in the Preamble of the Constitution, which is 'to participate toward the establishment of a world order based on freedom, perpetual peace and social justice'. Such statements, mostly made by senior diplomats, imply that there is still a strong tendency to argue that it is inappropriate to talk about direct benefits as if the government seeks 'rewards' for the good deeds that it does for others. However, discussions with some younger diplomats reveal a growing alternative view that now is the time for the government to start thinking about what real or tangible benefits to pursue if the country wishes to maintain its active role, particularly in the peacebuilding and peacekeeping fields. They argued that while such idealism is to a certain extent still valid, it is also important to think about how Indonesia's contributions can also serve the country's national interests in a more tangible way.

CSIS's earlier study on the SSTC described these complexities. The study, in which Indonesia's peacebuilding activities were included as one of country's niche capacities to share, concludes that SSTC activities so far have not had clear objectives. There are three categories of 'benefits' that can be applied to Indonesia's peacebuilding context. First, intangible benefits such as showing Indonesia's good will and solidarity toward other developing countries are emphasized. Second, while helping others, Indonesia can also benefit by learning from the experiences that the 
beneficiary/host countries go through. Third, while there might be some tangible political and economic benefits, it is always necessary to avoid imposing Indonesia's interests and agenda and to be as subtle as possible when dealing with this issue. This is crucial to maintain Indonesia's reputation among developing countries (CSIS 2014). ${ }^{8}$

In the peacebuilding context, the second 'benefit' above has been affirmed. Through its interactions with the partner countries, Indonesia has learned many useful lessons to help develop its democracy. One example, in Indonesia's engagement with Tunisia to help the country set up its election system, policymakers learned that Tunisia's election system ensures equal opportunity for women candidates to be elected by putting the names of men and women candidates alternately in the ballot papers for national and local elections. ${ }^{9}$

Another motivation is the aspiration to play a role as a middle power, which has to a certain extent influenced the initiative to embark on peacebuilding activities abroad. It is particularly based on the perception of Indonesia's identity as the biggest country in Southeast Asia in terms of size and population, and also as a proponent of the first Asia-Africa Conference in 1955, the largest association of developing countries. Additionally, the country perceives itself as having a distinct capacity that may not be inherited by others. Former President Yudhoyono, in the beginning of his first term, described the country as home to the world's largest Muslim population as well as the third largest democracy. Indonesia aspires to be a model, according to him, for how democracy, Islam, and modernity go hand-in-hand. Having this special quality, Indonesia envisions itself playing an active role as a peace-maker, confidence-builder, problem-solver, or bridge-builder that connects different countries and civilizations.

CSIS's study on Indonesia's SSTC activities ${ }^{10}$ makes a similar argument that the government tends to be subtle when discussing the tangible economic and political benefits of peacebuilding. According to the interviewees, this tone is struck to avoid the perception that Indonesia's vested interests and agenda are imposed on the recipient countries. This is important to ensuring that Indonesia's presence is accepted among host countries, so that it is perceived as an impartial/neutral actor and can continue its role as peace-maker or bridge-builder. Therefore, an important motivating factor for Indonesia's peacebuilding activities is to enhance its global presence and build its reputation as a responsible member of the international community that contributes significantly to the maintenance of international peace and security. There are three words, according to 
the study on Indonesia's SSTC, to describe its motivation: good will, solidarity, and presence (CSIS 2014, 84-85).

Finally, there are debates on the extent religious considerations influence the government's decisions about which countries Indonesia engages in. There has been clear and sustained pressure from Indonesia's Muslim majority public to persuade the government to assist Muslim communities that are facing discrimination and persecution in their home countries, both within the region (Southern Philippines, Southern Thailand, and currently Rohingya minorities in Myanmar) and further afield, such as in the Palestinian territories and Syria. ${ }^{11}$ However, as mentioned by one of Indonesia's leading international relations experts, this current focus on Islam as part of the country's national identity is relatively new, beginning in the post-Soeharto era, which commenced in 1999 while emphasizing that solidarity among developing countries often prevails over solidarity among Muslim countries (Anwar 2010,47).

Rather than simply invoking its Islamic identity, the country has a distinct aspiration to show how Islam can go hand-in-hand with democracy. This is due to what Indonesia perceives as its unique status as the world's largest Muslim population and the third largest democracy. Indonesia sees a niche in its engagement: emphasizing its Muslim identity to gain confidence from the host countries while promoting democracy as a key to sustaining peace.

\section{Debates on Aspects of Peacebuilding}

Since peacebuilding abroad is relatively new for Indonesia, there has been little debate on the subject to date. Nevertheless, from interviews conducted with government officials and peacebuilding activists in Indonesia, one important issue can be highlighted.

The most common debate centers on whether the country should actually play a role in helping other countries deal with their internal crises. While there has been a strong call from within Indonesia to play an active role to promote democracy abroad to exert its soft power, many officials possess self-awareness that the country is not in the best strategic position to play a significant role abroad due to internal political problems. Its democracy is still very much 'a work in progress' and faces many challenges (see Sukma 2012, 90 and Karim 2013). Some take the view that Indonesia's domestic challenges make it difficult to support democracy abroad. 


\section{Activities/Programs AND IMPACT}

Despite Indonesia's activism in peacebuilding, data on these activities are scattered and not well-documented in a single and centralized location. Nevertheless, some information can be gathered through the Ministry of Foreign Affairs (MoFA) and related institutions like the IPD.

In peacebuilding efforts related to the first area of democracy promotion and human rights, the government mostly conducts workshops, seminars, and trainings for the stakeholders in host countries. Two workshops appear in the online reports of the MFA's Directorate of Technical Cooperation (KST) within the period 2006-2013:

1. International Training Workshop on 'Democratization and Good Governance' held in Jakarta from October 28 to 31, 2008, organized by the Directorate of KST. The beneficiaries were participants from Timor Leste (four), Palestine (four); Cambodia (two); Lao PDR (two); Papua New Guinea (one), Viet Nam (two), and Indonesia (one).

2. International Workshop on Democracy Sharing Experiences Between Indonesia and Arab Countries held in Jakarta, Pekanbaru, and Bandung from September 13 to 20, 2013. The beneficiaries were from Jordan (five), Sudan (five), Somalia (one), Egypt (three), and Yemen (three).

Another source of Indonesia's peacebuilding activities is the Blue Book on Indonesia-Myanmar Capacity Building Partnership 2013-2015. That source reveals these activities within the peacebuilding framework (Table 3.1).

For such activities, government institutions, such as the Ministry of Foreign Affairs, Ministry of Law and Human Rights and Ministry of Defense, and other government-related institutions, such as the National Human Rights Commission, have been involved as the main actors. Among those activities, the Indonesian government has been very active in organizing the annual Bali Democracy Forum since December 2008. This Forum invites state leaders to discuss the development of democracy in the Asia-Pacific region. It is seeks to 'promote and foster regional and international cooperation in the field of peace and democracy through dialogue-based on sharing experiences and best practices that adhere to 
Table 3.1 Proposed peace-related Indonesian programs/activities in Myanmar (2013-2015)

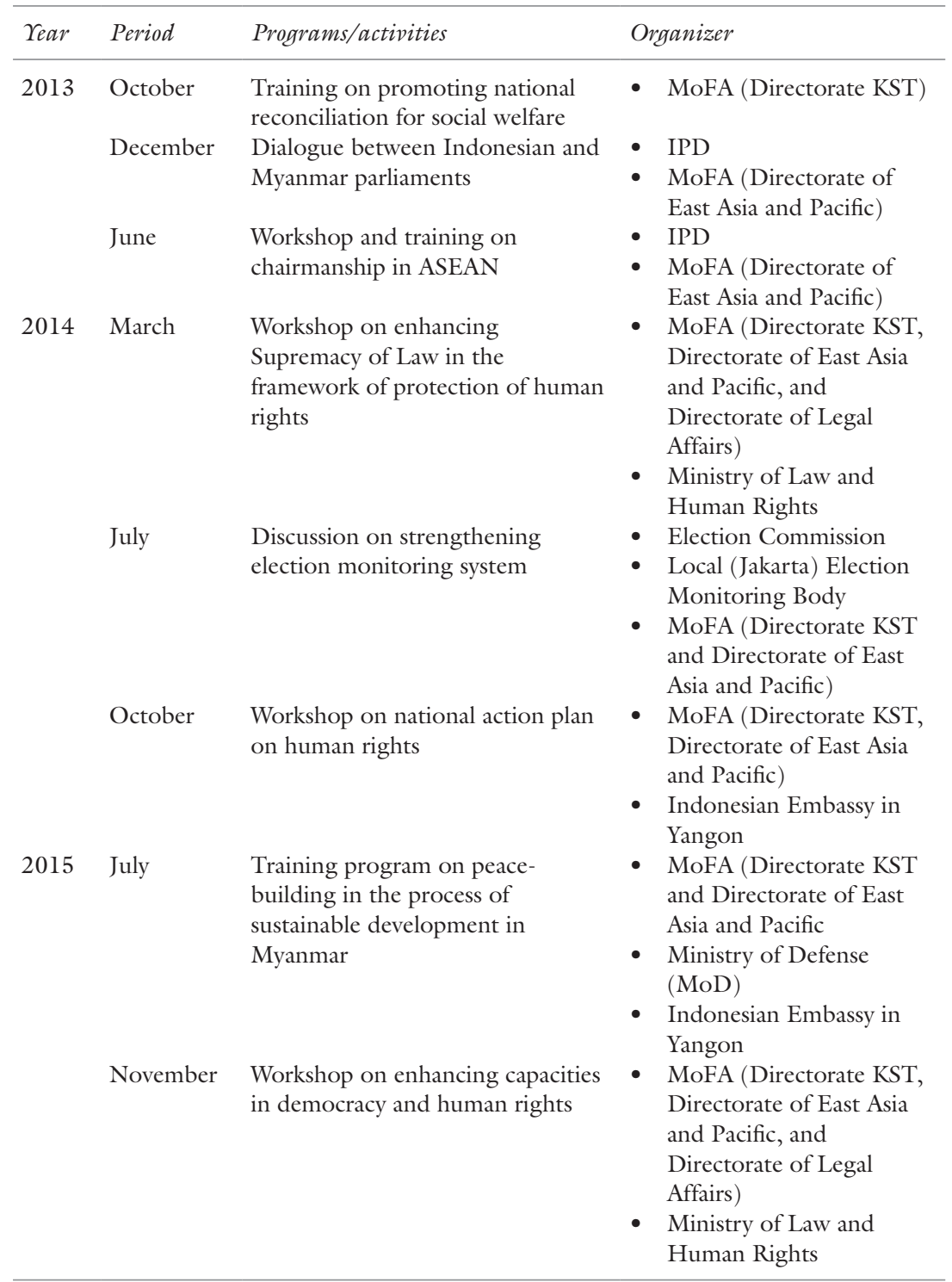

Source: Blue Book on Indonesia-Myanmar capacity building partnership 2013-2015 (Indonesian Ministry of Foreign Affairs 2013) 
the principle of equality, mutual respect and understanding, with the participating countries sharing its ownership'. ${ }^{22}$ The IPD was formed by the Ministry of Foreign Affairs with the support of Udayana University, based in Bali, to serve as the implementing agency for the Bali Democracy Forum. ${ }^{13}$

The mediation/facilitation/monitoring roles usually involved certain high-ranking active or ex-government officials or other prominent figures. The monitoring/observer role usually involved civil servants and military personnel, which was the composition of the Indonesian delegation that participated in the IMT in the Southern Philippines.

Finally, in the humanitarian actions area, the activities have been diverse, ranging from providing health facilities, building schools, natural disaster relief efforts to help the victims, to providing temporary shelters for the displaced Rohingya minorities.

\section{Budget}

Most of Indonesia's peacebuilding activities are funded through the national budget, but some activities receive funding or grants from external partners. Unfortunately, it is still difficult to determine the specific allocations from the national budget for Indonesia's SSTC, let alone activities related to capacity building in democracy and conflict resolution per se. While there may be some information available about the targeted countries and types of assistance, there is no specific information available about budget allocation for each program.

The activities to promote dialogues on democracy organized by IPD cost around US\$67,000 (IDR 800 million) per activity, which includes preliminary visits to conduct a needs assessment, consultations and networking with local stakeholders, and workshops and trainings. ${ }^{14}$ Since IPD is independent of the government, it seeks funding support from external partners, such as AusAID, USAID, and different foreign embassies in Indonesia, while cost-sharing has been utilized for some activities in collaboration with several ministries. ${ }^{15}$

Table 3.2 shows some pieces of information that can be traced from 2010 to 2014, which is related to Indonesia's peacebuilding activities abroad. 
Table 3.2 Indonesia's peacebuilding assistance in selected countries (2010-2014)

\begin{tabular}{|c|c|c|c|}
\hline Target country & Year & Form & Amount \\
\hline \multirow[t]{7}{*}{ Palestine } & 2014 & Aid & $\begin{array}{l}\text { USD } 5,00,000 \\
\text { (IDR } 1 \text { billion) }\end{array}$ \\
\hline & 2014 & Aid & USD I million \\
\hline & 2014 & Capacity building & USD 1.5 million \\
\hline & 2012 & Aid & USD $1,00,000$ \\
\hline & 2012 & Fund to develop cardiac center in Gaza & $\begin{array}{l}\text { USD } 2.1 \text { million } \\
\text { (IDR } 20 \text { billion) }\end{array}$ \\
\hline & 2010 & Aid & USD 20,000 \\
\hline & 2010 & Training for Palestinian businessman & $\begin{array}{l}\text { USD } 66,700 \text { (IDR } \\
600 \text { million) }\end{array}$ \\
\hline Myanmar & 2014 & Funding to build four schools & USD 1 million \\
\hline (Rakhine state) & 2013 & $\begin{array}{l}\text { Emergency relief and funding to } \\
\text { redevelop housings }\end{array}$ & USD 1 million \\
\hline South Thailand & 2013 & $\begin{array}{l}50 \text { scholarships for college students to } \\
\text { study at Islamic Universities in } \\
\text { Indonesia }\end{array}$ & $\mathrm{n} / \mathrm{a}$ \\
\hline Syria & 2014 & Aid & USD $5,00,000$ \\
\hline
\end{tabular}

Source: Author's compilation from different media sources

\section{Impact}

Just as it is difficult to put together a comprehensive and systematic accounting of Indonesia's peacebuilding activities, it is also hard to measure the impact of those activities on sustaining peace. As in the case of Indonesia's overall SSTC framework, the ultimate problem is that there have been no evaluation or monitoring mechanisms to date. There has been an absence of evaluations of completed projects, which could prove useful to assess which activities work and which do not (CSIS 2014, 55).

Thus far, the main indicator of success is positive feedback from the relevant stakeholders or follow-up requests from the host countries for further engagement, such as in Indonesia's engagement with Egypt in sharing its democratic experiences. ${ }^{16}$ Another example is the acknowledgement given by the highest leader of the Moro Islamic Liberation Front (MILF) ), Al Haj Murad Ebrahim, in support of Indonesia's continuing role with the IMT in ensuring the success of the peace process in the Southern Philippines (Ladiasan 2014). In addition, Myanmar President Thein Sein 
asked Indonesia to assist his country in resolving ethnic tensions, particularly those involving the Rohingya people. Moreover, the Myanmar government also indicated its hope and support for Indonesian private sector investment in the Rakhine state-the area where most Rohingya people live-in order to create more jobs to ease the social and economic problems there (Santosa 2012).

In the case of ASEAN, the achievements, interestingly, have been measured in terms of the ability of some ASEAN countries to 'unite'. The Aceh Monitoring Mission (AMM) to conduct peacebuilding tasks, mainly to monitor the decommissioning of GAM (the separatist Free Aceh Movement group) weapons, redeployment of the Indonesian security forces, reintegration of ex-combatants into the society, as well as the legislative process have been deemed at least a partial success due to the participation of some ASEAN member states (Brunei, Malaysia, the Philippines, Singapore, and Thailand), including Indonesia, which made the mission impartial, without denying the significant support given by some European Union member states during the early phase of AMM. There was even a proposal to make AMM a model for future cooperation in crisis management between regional actors (Feith 2007, $1-7)$.

This can also be seen in the establishment of the IMT-in which Indonesia, Malaysia, and Brunei participated-to monitor the implementation of the peace agreement between the Government of the Philippines and MILF. In fact, the consent from the host country, as shown by the Indonesian and the Philippines governments, for ASEAN or some ASEAN member states, in collaboration with external partners to conduct peacebuilding activities, is by itself already an indicator of achievement.

\section{Conclusions and Way Forward}

The account above demonstrates that Indonesia views its peacebuilding role as part of its overall assistance and cooperation with other countries, particularly fellow developing countries. While some peacebuilding efforts entailed humanitarian actions, including aiding the people in host countries with some economic assistance, the government tends to separate peacebuilding efforts from 'routine' development assistance that supports economic and socio-cultural ends. In its peacebuilding efforts, Indonesia focuses more on sharing capacities in the political field, particularly by 
sharing its democratic and human rights values and playing a mediation or facilitation role.

Rather than having a rigid template to be brought to the host countries, Indonesia tends to approach them with a 'blank sheet'. Indonesian diplomats and analysts interviewed for this study suggest that Indonesia often takes a longer time to explore the needs of respected countries while opening up genuine communications with different local stakeholders both from government and non-governmental actors. Indonesia believes that each country has its own strengths. Indonesia's role is to support each country as it crafts its own peacebuilding process, rather than pushing it from the outside. This approach contributes to the establishment of a sense of national ownership, which is critical to ensure the success of any peacebuilding effort. Furthermore, a persuasive approach is necessary in peace efforts in order not to challenge the government's sovereignty. The demand for learning from Indonesia's experiences should come from the host countries, rather than being imposed by the Indonesian government.

Indonesia emphasizes a mutual learning process when conducting peacebuilding activities. Rather than the partner countries simply learning from Indonesia's experiences, it is always a two-way exercise in which Indonesia also learns from the other side. Since Indonesia, in its encounter with partner countries, is willing to divulge that it is also still struggling with many internal problems that threaten sustainable peace, partner countries are persuaded of the value of Indonesia's role, especially to be open in exploring and discussing their problems. This first step is crucial to the process of finding solutions.

However, Indonesia's peacebuilding role faces many challenges. The first challenge comes from within the government: a lack of coordination among different government institutions. Within the Ministry of Foreign Affairs, for example, several directorates handle peacebuilding in Myanmar. Based on geography, Myanmar is handled under the responsibility of the Directorate of ASEAN Political Affairs and Security, as well as the Directorate for East Asia and Pacific. Peacebuilding is also categorized as part of Indonesia's public diplomacy, and some activities are coordinated by the Directorate of Technical Cooperation under the DirectorateGeneral of Public Diplomacy. Other activities involve other ministries or agencies such as the police or military institutions.

The second challenge is the lack of detailed and centralized databases containing records on peacebuilding programs and activities. Related to 
this is the dearth of standardized monitoring and evaluation mechanisms to measure achievements as well as mistakes in order to make improvements. So far each institution generally keeps its own notes on evaluations, if any. However, the public rarely has access to such notes and reports.

Third, while there is much research to be done, Indonesia's niche capacities and distinct approach in conducting its peacebuilding in the region, as well as in the global arena, represent a distinct contribution. Its approach reflects broader approaches of rising powers that ultimately fill gaps left by the efforts of traditional Western actors.

Rather than competing, the different approaches taken by traditional actors and rising powers complement one another. Traditional actors have provided useful guidelines that define peacebuilding and list the essential activities and principles that must be applied in order to sustain peace in the long run. Nevertheless, the distinct approaches introduced by rising powers are also important, since these actors' recent experiences with peacebuilding within their own borders provide a certain legitimacy. These approaches emphasize the need to respect the host country's sovereignty, as well as the importance of gaining confidence and trust from the very beginning of the peacebuilding process and working at a pace that is comfortable for local stakeholders.

However, rising actors still face challenges, mainly in securing funding to sustain their global and regional peacebuilding activities. Traditional actors can play a role in collaborating with the rising powers to conduct peacebuilding activities. Through the framework of triangular cooperation, traditional peacebuilding actors can provide funding for the programs initiated and designed by the rising actors. Traditional actors can also help rising powers frame their experiences more effectively. UNDP, for example, has a depth of knowledge in peacebuilding projects as well as how to monitor the implementation of those projects in a professional manner. Such knowledge is important to transform rising powers into more advanced actors in peacebuilding. However, it is important that they bring their own distinctive experiences and wisdom to their peacebuilding efforts.

Finally, consolidation of Indonesia's own material capabilities is important to sustain the expansion of its peacebuilding activities, particularly if Indonesia wishes to continue its role as peace facilitator/mediator. Using soft power is indeed important and useful, but not enough. By doing so, Indonesia can regain its leadership in the region and enhance its global role. 


\section{Notes}

1. ASEAN Charter, article 2.

2. In the Draft Grand Design for Indonesia's South-South Triangular Cooperation, there are seven program priorities mentioned. The other six programs are capacity building in the field of trading and export; infrastructure and road construction program; family planning and reproductive health program; scholarship for developing countries; capacity building in macro-economy, public finance, and micro-economy; and capacitybuilding in the field of community empowerment. It should be noted that the Grand Design is in the form of final draft that is still awaiting the government's promulgation.

3. Similar to the Grand Design, this Blue Print also awaits the government's promulgation. The other comparative advantages are poverty reduction; agriculture and food security; infrastructure; disaster and climate change risk management: human resource development; development of science; socio-cultural development; macro-economy, economic management, and public finance; and microfinance; trading, service, and investment. Peacebuilding is listed as number 6 in the list.

4. According to the final draft of the Grand Design of Indonesia's SSTC, there are seven program priorities: (1) capacity-building in democracy and conflict resolution; (2) capacity-building in the field of trading and export; (3) infrastructure and road construction program; (4) family planning and reproductive health program; (5) scholarship for developing countries; (6) capacity-building in macro-economy, public finance, and micro-economy; and (7) capacity-building in the field of community empowerment.

5. See, for example, the transcript of interview conducted by the International Business Times with Dilshod A. Achilov, Professor of Political Science at Tennessee State University, who is an expert on the Middle East and Islam in Palash Ghosh, 'Arab nations may look to Turkey and Indonesia as models of modern Islamic states', in http://www.ibtimes.com/arab-nationsmay-look-turkey-indonesia-models-modern-islamic-states-part-1-272111 and http://www.ibtimes.com/arab-nations-may-look-turkey-indonesiamodels-modern-islamic-states-part-2-272119.

6. An interesting story about the prominent facilitator from Malaysia of the Southern Philippines talks, Datuk Tengku Abdul Ghaffar Tengku Mohd, can be viewed in an article by Razak Ahmad, 'Holding peace talks over a cuppa', October 21, 2012, http://www.thestar.com.my/News/ Nation/2012/10/21/Holding-peace-talks-over-a-cuppa/. For more details about the roles of ICG, read Conciliation Resources, Innovation in Mediation Support: The International Contact Group in Mindanao at 
http://www.c-r.org/resources/practice-paper-innovation-mediationinternational-contact-group-mindanao and Democratic Progress Institute, Briefing: International Contact Group for the Southern Philippines Peace Process, 2014, at http://www.democraticprogress.org/briefinginternational-contact-group-for-the-southern-philippines-peace-process/.

7. Interview with Ambassador Artauli RMP Tobing in Jakarta, June 18, 2015.

8. Centre for Strategic and International Studies, Study on Policy Implementation and Funding Partnership Strategy of South-South and Triangular Cooperation, August 2014. This report is part of the Capacity Development Project for South-South and Triangular Cooperation (CADEP-SSTC): a cooperation between the Government of Indonesia, through the National Coordination Team on South-South and Triangular Cooperation (NCT-SSTC), and the Government of Japan, through the JICA Indonesia Office.

9. Interview with Dr. I Ketut Erawan, Executive Director of the IPD, June $17,2015$.

10. This report is part of the CADEP-SSTC: a cooperation between the Government of Indonesia, through the NCT-SSTC, and the Government of Japan, through the JICA Indonesia Office.

11. See, for example: 'ASEAN urged to pressure Myanmar over Rohingya crisis', The Jakarta Post, June 3, 2015, http://www.thejakartapost.com/ news/2015/06/03/asean-urged-pressure-myanmar-over-rohingya-crisis. html.

12. 'What is the Bali Democracy Forum?', http://bdf.kemlu.go.id/index. php?option $=$ com_content\&view $=$ article $\&$ id $=445 \&$ Itemid $=106 \&$ lang $=e n$.

13. IPD has just recently in the mid-2015 gained its independent legal status as a foundation that makes it no longer under the special status in connection with Udayana University.

14. Interview with Dr. I Ketut Erawan, Executive Director of IPD, June 17, 2015.

15. The supporting embassies are, for example, Embassy of Netherlands, New Zealand Embassy, Norwegian Embassy, Embassy of Japan, and Embassy of Switzerland-see http://www.ipd.or.id/about-ipd/partners-and-donors.

16. Interview with Dr. I Ketut Erawan, Executive Director of IPD, June 17, 2015.

\section{REFERENCES}

Adamrah, Mustaqim. 2011. Myanmar Set to Chair ASEAN: FM. The Jakarta Post, November 16.

Alatas, Ali. 2001. A Voice for a Just Peace: A Collection of Speeches by Ali Alatas. Jakarta: PT Gramedia. 
Alford, Peter. 2011. Indonesia a Model for Arab Uprisings. The Australian, August 27.

Antara News. 2017. Indonesia Proposes Four Actions for Rakhine. Antara News, January 21. Accessed January 23, 2017. http://www.antaranews.com/en/ news/109037/indonesia-proposes-four-actions-for-rakhine.

Anwar, Dewi F. 2010. Foreign Policy, Islam and Democracy in Indonesia. Journal of Indonesian Social Sciences and Humanities 3: 37-54.

Centre for Strategic and International Studies. 2014. Study on Policy Implementation and Funding Partnership Strategy of South-South and Triangular Cooperation. Jakarta.

Eliraz, Giora. 2014. Indonesian Democracy Comes to Tunisia. Australia Israel and Jewish Affairs Council (AIJAC), March 19. Accessed January 23, 2017. http://www.aijac.org.au/news/article/indonesian-democracy-comes-totunisia.

Fan, Lilianne and Hanna B. Krebs. 2014. Regional Organisations and Humanitarian Action: The Case of ASEAN. Humanitarian Policy Group Working Paper.

Feith, Pieter. 2007. The Aceh Peace Process: Nothing Less than Success. United States Institute of Peace Special Report 184:1-7. Accessed January 30, 2017. http://www.usip.org/sites/default/files/srl84.pdf.

Hotland, Tony. 2008. Indonesia Defends Stance on UN Role in Myanmar. The Jakarta Post, May 15.

Indonesian Ministry of Foreign Affairs. 2013. Blue Book on Indonesia-Myanmar Capacity Building Partnership 2013-2015.

Karim, M. Faisal. 2013. Indonesia Should Promote Democracy Globally, Starting with Egypt. East Asia Forum. http://www.eastasiaforum.org/2013/08/22/ indonesia-should-promote-democracy-globally-starting-with-egypt/

Kompas. 2012a. Indonesia Has a Big Role in Myanmar [Indonesia Punya Peran Besar di Myanmar]. Kompas February 3.

- 2012b. Myanmar: Indonesia Mungkin Ikut Pantau Pemilihan Umum [Myanmar: Indonesia May Join to Monitor Election]. Kompas January 5.

Ladiasan, R.T. 2014. Chairman Murad Thanks Indonesia for Sending New Contingent with IMT. http://afrim.org.ph/newafrim/tag/internationalmonitoring-team-imt

Leifer, Michael. 1983. Indonesia's Foreign Policy. London: George Allen \& Unwin. Maulida, Erwida, and Mustaqim Adamrah. 2011. RI Set to Help Democratize Myanmar. The Jakarta Post, December 29.

Narine, Shaun. 1998. ASEAN and the Management of Regional Security. Pacific Affairs 71(2): 195-214.

Santosa, Novan I. 2012. Myanmar Asks RI to Help Settle Rohingya Problem. The Jakarta Post, November 21.

Sastrohandoyo, Wiryono. 2008. Indonesia and Southeast Asian Territorial Peace Process. Asia Europe Journal 6(1): 15-30. 
Sukma, Rizal. 2012. Domestic Politics and International Posture: Constraints and Possibilities. In Indonesia Rising: The Repositioning of Asia's Third Giant, ed. Anthony Reid. Singapore: ISEAS.

Tan, Paige J. 2007. Navigating Turbulent Ocean: Indonesia's Worldview and Foreign Policy. ASIAN Perspective 31(3): 147-181.

Taufiqurrahman, M. 2012a. Kalla Pledges Aid to Myanmar Rohingya. The Jakarta Post, September 10.

- 2012b. Former RI VP Joins Myanmar Peace Process. The Jakarta Post, September 11 .

The Jakarta Post. 2010. Foreign Help not Needed in Southern Thailand: PM. The Jakarta Post, July 27.

Weatherbee, Donald E. 2005. Indonesian Foreign Policy: A Wounded Phoenix. Southeast Asian Affairs 1: 150-170.

Widyaningsih, Erlina, and Christopher B. Roberts. 2014. Indonesia in ASEAN: Mediation, Leadership, and Extra-mural Diplomacy. National Security College Issue Brief 13: 105-116. Accessed January 30, 2017. http://nsc.anu.edu.au/ documents/Indonesia-Articlel3.pdf

Wulan, Alexandra R., and Bantarto Bandoro. 2007. ASEAN's Quest for a Fullfledged Community. Jakarta: CSIS.

Yudhoyono, Susilo B. 2005. Transforming Indonesia: Selected International Speeches. Jakarta: Office of Special Staff of the President for International Affairs.

Lina A. Alexandra is Senior Researcher, Centre for Strategic and International Studies (CSIS), Jakarta.

Open Access This chapter is licensed under the terms of the Creative Commons Attribution 4.0 International License (http://creativecommons.org/licenses/ by $/ 4.0 /)$, which permits use, sharing, adaptation, distribution and reproduction in any medium or format, as long as you give appropriate credit to the original author(s) and the source, provide a link to the Creative Commons license and indicate if changes were made.

The images or other third party material in this chapter are included in the chapter's Creative Commons license, unless indicated otherwise in a credit line to the material. If material is not included in the chapter's Creative Commons license and your intended use is not permitted by statutory regulation or exceeds the permitted use, you will need to obtain permission directly from the copyright holder.

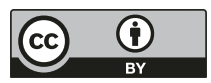

